\title{
KAJIAN TIPOLOGI KUIL HINDU TAMIL PADA BANGUNAN GRAHA KATOLIK ANNAI VELANGKANNI DI MEDAN
}

\author{
Polin DR Naibaho, ST., MT \\ Program Studi Arsitektur, Fakultas Teknik, Universitas Katolik Sumatera Utara, Jalan Setia Budi No.479 F Medan
}

\begin{abstract}
The aim of this research is to identify the typology of Tamil Hindu temples were used on the architectural design of Graha Katolik Annai Velangkanni. As for the results of the research are Graha Katolik Annai Velangkanni adopted a form of Dravidian Tamil Hindu typology Style located in South India, with a pyramid-shaped tower with a shrink over the stair steps. It has seven levels of the building that symbolizes perfection and seven heavens, as well as three dome that symbolizes to Holy Trinity. One of the uniqueness in adopting the form of the Hindu Tamil Temple is in the zone of the altar (2nd floor), there is the opening up penetrate to the rear Tower as a place to enter the light from above so that the space feels more sacred altar with its natural lighting from the top of the tower. This typology is drawn from the concept of typology building Hindu temples namely space garbaha griha who continuously to the tower roof of vemana. The adoption of the other elements is taken from the form of animals (Peacock) and plants (Lotus, kalpataru and banana trees) where the ornaments found in the temples of Shrie Mariamman is a person (God), animals (elephants, birds) and plants (Lotus).
\end{abstract}

\section{Keywords : typology, temple, hindus, chatolic, tamil}

\begin{abstract}
Abstrak
Tujuan dari penelitian ini adalah identifikasi tipologi Kuil Hindu Tamil yang digunakan pada bangunan Graha Katolik Maria Annai Velangkani. Adapun hasil dari penelitian adalah bangunan Graha Katolik Maria Annai Velangkani mengadopsi bentuk tipologi kuil Hindu Tamil Dravida Style yang terletak di India Selatan, dengan menaranya berbentuk piramida dengan undakan yang makin mengecil keatas. Graha Maria Annai Velangkani memiliki tujuh tingkatan bangunan yang melambangkan kesempurnaan dan tujuh langit, serta tiga kubah yang melambangkan Ke-Tri Tunggalan Allah. Salah satu keunikan dalam mengadopsi bentuk dari kuil Hindu Tamil adalah pada zona altar, terdapat bukaan atas yang tembus ke menara belakang sebagai tempat memasukkan cahaya dari atas sehingga ruang altar terasa lebih sakral dengan adanya pencahayaan alami dari atas menara. Tipologi ini diambil dari konsep tipologi bangunan kuil Hindu yaitu ruang garbaha griha yang menerus ke menara atap vemana. Pengadopsian unsur yang lain adalah pada ornamen Graha Maria Annai Velangkanni yang banyak mengambil bentuk hewan (burung merak) dan tumbuhan (teratai, kalpataru dan pohon pisang) dimana ornamen yang terdapat pada kuil Shrie Mariamman adalah orang (dewa), hewan (gajah, burung) dan tumbuhan (teratai).
\end{abstract}

\section{Kata Kunci: tipologi, kuil, hindu, katolik, tamil \\ 1. Pendahuluan}

Graha Maria Annai Velangkanni merupakan Graha inkulturatif Indo-Mongol/ Indo-Mughal.Tempat suci yang dibangun pada tanggal 8 September 2001, tepatnya saat perayaan kelahiran Bunda Maria ini dimaksudkan untuk menghormati Santa Maria, Bunda Penyembuh yang dikenal sebagai Annai Vekangkanni. Graha Maria Annai Velangkanni dalam Bahasa Inggris berarti Home of Mary of Good Health. Hal tersebut bermula atas inisiatif dan usaha Pastor James Bhrataputra S.J., seorang Jesuit Misionaris asal India yang sudah lebih dari 30 tahun berkarya di Keuskupan Agung Medan, yang secara khusus ikut melayani 12 tahun umat India Tamil yang telah datang ke Sumatera. 


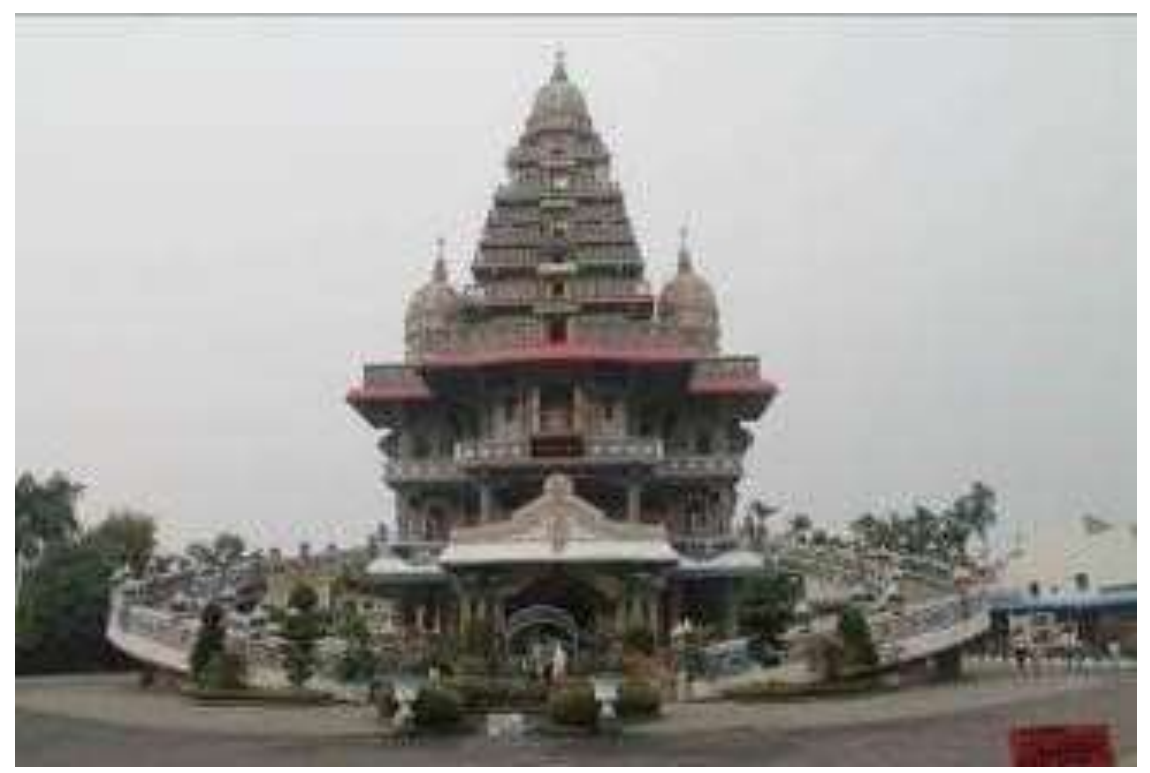

Gambar 1. Graha Maria Annai Velangkanni

(Sumber: Dokumentasi, Polin N, 2016)

Graha Maria Annai Velangkanni merupakan sebuah bangunan serbaguna katolik di Medan yang mencirikan harmonisasi dalam kepluralitasan agama dan budaya. Bangunan tersebut berupa perpaduan bentuk ikonik menara candi dengan kubah serta arsitektur Graha Katolik. Sebuah perpaduan budaya yang tidak biasa bagi sebuah bangunan katolik, di mana Graha Maria Annai Velangkanni ini tidak memiliki visualisasi seperti bangunan atau gereja Katolik pada umumnya..

Keunikan bentuk dari Graha Katolik Maria Annai Velangkanni ini yang tidak biasa pada bentuk tipologi Graha katolik umumnya yang cenderung memiliki fasad (wajah) bangunan dengan dinding bata dan bentuk dasar persegipanjang, menjadi dasar bagi peneliti mengambil objek penelitian. Tidak akan ditemukan atap Graha yang menjulang dan lancip, flying-butress, tapi justru berupa bangunan yang menyerupai candi-candi di India

Tentunya hasil penelitian ini diharapkan nantinya menjadi data dan sumber informasi bagi pengembangan teknik mendesain objek arsitektural sejenis.

Penelitian dilakukan pada unsur-unsur tipologi serta komposisi bangunan kuil Hindu Tamil yang dipakai pada bangunan Graha khatolik Graha Maria Annai Velangkanni sehingga menghasilkan suatu bangunan yang inkulturatif (dapat mengadopsi budaya lokal setempat, dalam hal ini kuil Hindu Tamil). Penelitian akan dilakukan pada bagian facade (wajah) luar bangunan dan bagian interior bangunan.

Tujuan dari penelitian ini adalah identifikasi tipologi Kuil Hindu Tamil yang digunakan pada desain arsitektur Graha Katholik Annai Velangkani

Manfaat dari penelitian ini diharapkan dapat untuk:

Memperluas wawasan dan ilmu pengetahuan, terutama dalam penerapan Tipologi, simbol, filosofi suatu objek bangunan pada bangunan lain

Membuka wawasan untuk pengembangan desain suatu bangunan yang kreatif yang tidak monoton mengambil bentuk berdasarkan tipologi yang sudah ada.

\section{Tinjauan Pustaka}

Pengertian tipologi secara umum adalah ilmu yang mempelajari segala sesuatu mengenai tipe. Kata type berasal dari bahasa Yunani yaitu typos yang berarti indicative of (menunjuk pada, menandakan pada), applicable of. Dan banyak juga variasi-variasi dari kata tersebut yang mempunyai arti yang hampir sama yaitu model, matriks, impression, mold dan relief (Bernard, 1997).

Dalam buku 'Ordering Space', a type is kind of thing and an exemplar of a kind of thing. Type is conceptual construct that distinguishes similar from dissimilar so that we know that something is kind of thing, not that kind of thing (Frank, 1994). yang dalam terjemahan bebasnya, tipe adalah sebuah gambaran dari apa yang kita pikirkan, dan juga tipe adalah konsep rancang dari suatu similar (analogi) 
Jurnal Arsitektur AIJR - Vol 3 No 1 Mei 2020

e-ISSN 2685-1490; p-ISSN 2615-1472

dan disimilar (methapor) sehingga kita mengetahui sesuatu yang kita ketahui sesuatu yang bukan berasal dari sesuatu.

- $\quad$ Tipe digunakan sebagai sesuatu yang mempunyai wujud atau gambaran, tetapi ada juga yang hanya digunakan hanya sebagai hayalan. Tipe-tipe yang ada dapat kita gunakan sebagai penunjuk atau pengenalan terhadap apa saja yang berada di bumi ini, contohnya menunjukkan tipe bangunan. Hal ini dihadirkan agar memudahkan kita sebagai perencana atau arsitek untuk mencari image awal dan juga akhir pada suatu hasil karya. Konsep dari tipe sebagai ide adalah untuk mengetahui arsitektur sebagai ilmu praktis, teori dan penelitian.

- $\quad$ Tipe adalah kategori yang kita gunakan untuk mendefenisikan dunia di sekitar kita. Mereka merupakan bentuk-bentuk ideal dengan nama-nama yang telah disetujui secara umum yang menunjukkan sekelompok objek nyata (Frank, 1994).

Menurut Budi A. Sukada, tipologi adalah penelusuran asal usul terbentuknya objek-objek arsitektural yang terdiri dari tiga hal yaitu:

1. Menentukan "bentuk-bentuk dasar" yang ada di dalam tiap objek arsitektur.

2. Menentukan "sifat-sifat dasar" yang dimiliki oleh setiap objek arsitektural berdasarkan bentuk dasar yang ada padanya.

3. Mempelajari proses perkembangan bentuk dasar.

Bentuk dasar yang dimaksud disini adalah unsur-unsur geometrik utama seperti segitiga, segi empat, lingkaran dan elips; berikut segala variasi masing-masing unsur tersebut. Dan yang dimaksud dengan sifat dasar ialah hal-hal seperti : memusat, memencar, simetris, statis, sentris dan sebagainya. Misalnya: sebuah lingkaran mempunyai sifat dasar "memusat".

Tiga alasan pentingnya tipologi dalam arsitektur, yaitu antara lain:

1. Membantu proses analisis terhadap objek arsitektur yang sudah ada (dalam hal ini berfungsi sebagai penggambaran objek)

2. Berfungsi sebagai media komunikasi, dalam hal ini terkait dengan transfer pengetahuan

3. Membantu kepentingan proses mendesain (membantu menciptakan produk baru).

\subsection{Tipologi Bentuk Kuil Shri Mariamman}

Tata ruang bangunan Kuil Shri Mariamman (Putri Indah Sari, Kajian Karakteristik Arsitektur Hindu Pada Kuil Shri Mariamman Medan) terdiri dari :

1. Garbaha Griha (en.wikipedia.org/wiki/Garbaha Griha), terletak dalam kuil dengan menara atau Vimana,

Ruang ini ditempatkan langsung di bawahnya, dan membentuk sumbu vertikal utama candi. Hal tersebut dapat dipahami untuk mewakili sumbu dunia melalui Gunung Meru. Garbaha Griha biasanya juga membentuk sumbu horisontal utama candi yang umumnya sumbu timur-barat. Pada kuil lain yang di mana ada juga sumbu silang, posisi garbaha griya terletak dititik persimpangannya.

Umumnya Garbaha Griha adalah tanpa jendela dan jarang ada cahaya, sengaja dibuat demikian untuk memfokuskan pikiran pemuja pada bentuk nyata dari ilahi di dalamnya. Masuk ke garbaha graha hanya diperbolehkan pada imam yang melakukan layanan di sana..yang ada pada Kuil Shri Mariamman terletak pada bagian atas bangunan dan merupakan salah satu tempat paling suci. Garbaha Griha pada Kuil Shri Mariamman sering disebut juga dengan "Vimana". Bentuk Garbaha Griha pada kuil ini semakin keatas semakin mengecil, seperti bentuk sebuah piramid.

Pada umumnya Garbaha Griha lebih sering dibangun dalam bentuk persegi di atas teras atau landasan. Tetapi untuk kuil-kuil yang dibangun bagi dewi-dewi, garba griha berbentuk persegi panjang. Seperti di Kuil Shri Mariamman yang di gambarkan sebagai ibu pelindung. Garbaha Griha pada Kuil Shri Mariamman Medan berwarna kuning keemasan dan terdiri atas 2 tingkatan. Pada Garbaha Griha ini terdapat banyak ornamen khas india, seperti patung dan ornamen binatang dan juga bentuk berbagai Dewa. 


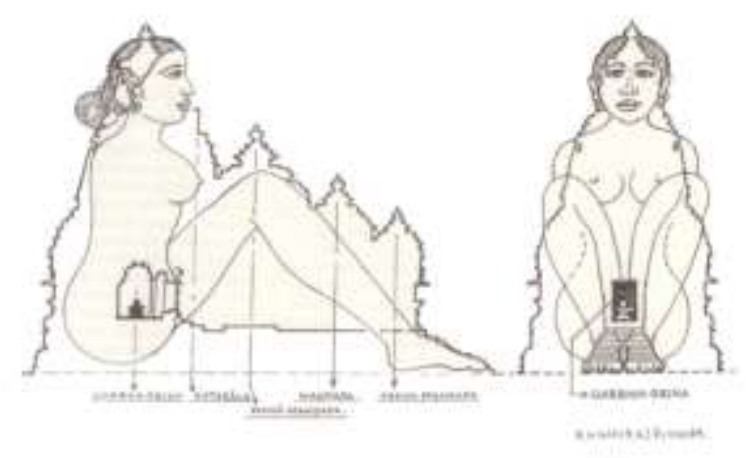

Gambar 2 Filosofi Garbaha Griha dalam ruang pada Kuil Hindu

(Sumber: http://arjuna-vallabha.tumblr.com)

2. Teras/Pelataran/Mandapa (en.wikipedia.org/wiki/Mandapa) adalah struktur teras berbentuk persegipanjang yang menghubungkan gopura (tiang gerbang dengan ornamen) menuju ke kuil.

Ruang Mandapa digunakan untuk tarian keagamaan yang diiringi musik dan merupakan bagian dari kompleks kuil. Ruang doa umumnya dibangun di depan Garbaha Griha. Sebuah kuil besar akan memiliki banyak Mandapa.

Jika sebuah kuil memiliki lebih dari satu mandapa, masing-masing dialokasikan untuk fungsi yang berbeda dan diberi nama untuk mencerminkan penggunaannya. Misalnya, mandapa didedikasikan untuk pernikahan ilahi disebut sebagai mandapa Kalyana. Mandapa juga merupakan tempat di mana pernikahan Hindu dilakukan. Pengantin mengelilingi api suci dipimpin oleh imam di tengah Mandapa tersebut.

Pelataran Depan/Mandapa halaman pada Kuil Shri Mariamman berbentuk persegi dan berada pada sekeliling kuil, yang dimana biasa disebut dengan Mandapa. Mandapa terletak tepat pada belakang gerbang masuk utama kuil. Mandapa dikelilingi oleh dinding-dinding dan pada dinding-dinding tersebut terdapat 2 (dua) buah pintu.

Pada dinding pembatas Mandapa terdapat ornamen dan gambar Dewa-Dewa yang menghiasi dinding tersebut. Penutup lantai pada Mandapa terbuat dari pavling block berwarna merah bata. Pada Mandapa terdapat 2 buah tempat seserahan.

3. Gopura atau di sebut juga dengan gerbang abadi (en.wikipedia.org/wiki/Gopura), merupakan sebuah penghubung atau jalan menuju ke dalam kuil.

Sebuah gopura biasanya berbentuk persegi panjang yang berada pada depan bangunan Vimana Garbaha Griha dengan banyak sekali ornamen dan detail patung. Patung dan ornamen dicat dengan berbagai warna dan tema yang berasal dari mitologi Hindu, terutama yang berhubungan dengan di mana gopura berada. Arah vertikal keatas bentuk gopura mulai meruncing, dibagi menjadi beberapa lantai yang menyempit. Pada Kuil Shri Mariamman hanya terdapat satu buah Gopura. Pintu gerbang atau Gopura yang ada di Kuil Shri Mariamman Medan di hiasi sebuah gopura, yaitu menara bertingkat yang biasanya dapat ditemukan di pintu gerbang kuil-kuil Hindu dari India Selatan atau semacam gapura. Pada awal pembangunan kuil, detail ornamen dicat dengan warna-warni yang beragam sehingga menimbulkan efek kaya warna, pada perkembangannya ornamen pada gopura Shri Mariamman seluruhnya dicat warna emas. 


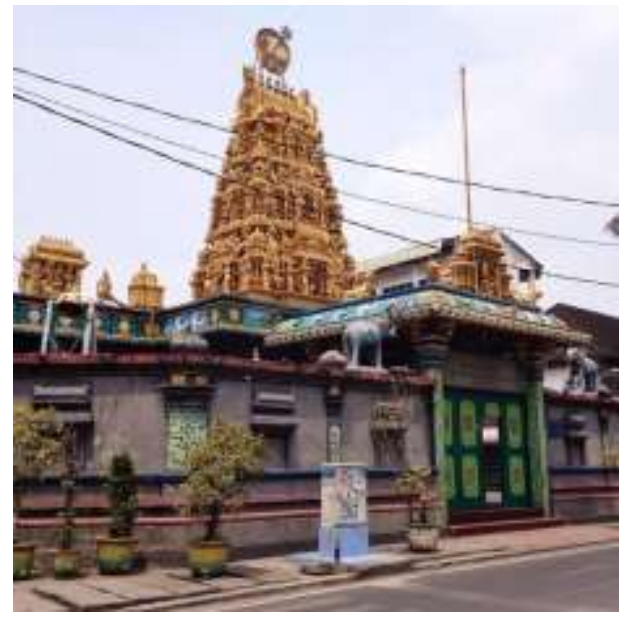

Gambar 3 Gopura pada Kuil Shri Mariamman

(Sumber: dokumentasi, Polin N, 2016)

\subsection{Denah Kuil Shri Mariamman}

Bentuk dasar denah pada Kuil Shri Mariamman berbentuk persegi panjang dengan ukuran $12 \mathrm{~m} x$ $27 \mathrm{~m}$. Pada bagian dalam kuil terdapat beberapa ruangan yaitu, sebuah ruang suci sebagai tempat penyembahan yang berukuran $4 \mathrm{~m} \times 4 \mathrm{~m}$ dan juga ruang suci tambahan yang berukuran $2 \mathrm{~m} \times 2 \mathrm{~m}$. Ruang suci utama merupakan ruangan yang paling sakral dan paling suci pada kuil ini. Terdapat beberapa patung gajah dan dewa-dewa lainnya yang menghiasi ruangan ini. Selain ruang suci utama, terdapat juga dua buah ruang suci yang berukuran lebih kecil yaitu $2 \mathrm{~m} \times 2 \mathrm{~m}$. Ruangan ini juga digunakan untuk bersembahyang. Ruang tambahan ini terletak pada sisi kanan dan kiri ruang suci utama. Terdapat beberapa patung dewa pada bagian dalam ruangan ini.

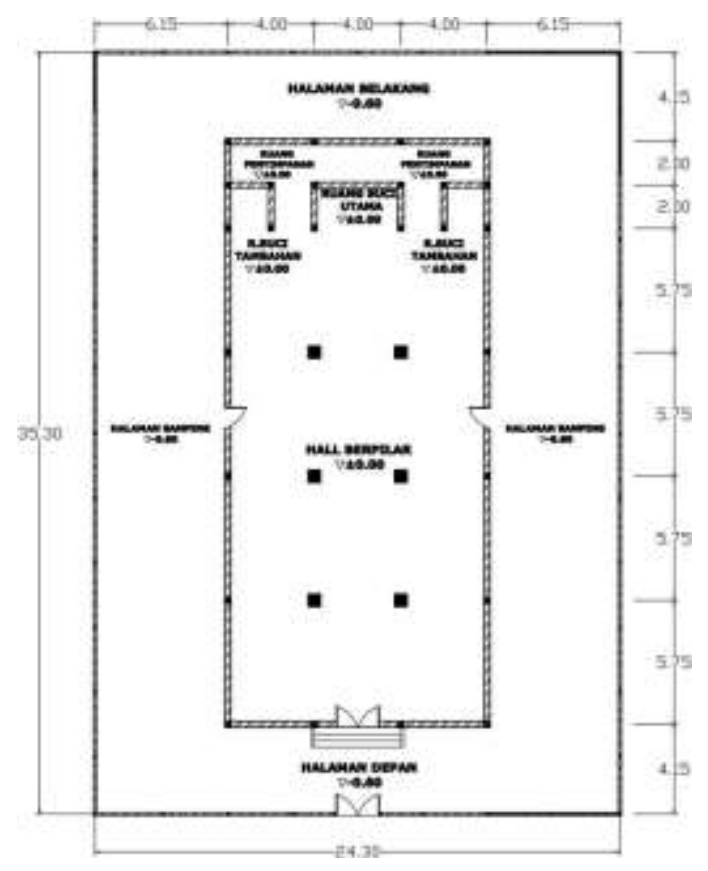

Gambar. 4 Denah interior Kuil Shri Mariamman (Sumber: dokumentasi, Polin N, 2016) 
Gambar 4 memperlihatkan adanya arah sirkulasi kearah Timur-Barat dengan arah panah tebal yang menunjukkan arah sembahyang umat dimana arah Ruang Suci mengarah ke Timur dan umat menghadap ke Barat. Arah panah yang tipis menunjukkan ruang sirkulasi untuk pintu masuk kehalaman samping kuil. Ada tiga ruangan yang dijadikan tempat sembahyang. Salah satunya di ruang utama. Sebuah ruangan yang terdapat Arca Dewi Mariamman di dalamnya. Di kanan ruangan itu terdapat altar Shri Murugar. Sedangkan di sebelah kiri adalah altar Shri Vinayagar, yang lebih dikenal sebagai Dewa Ganesha

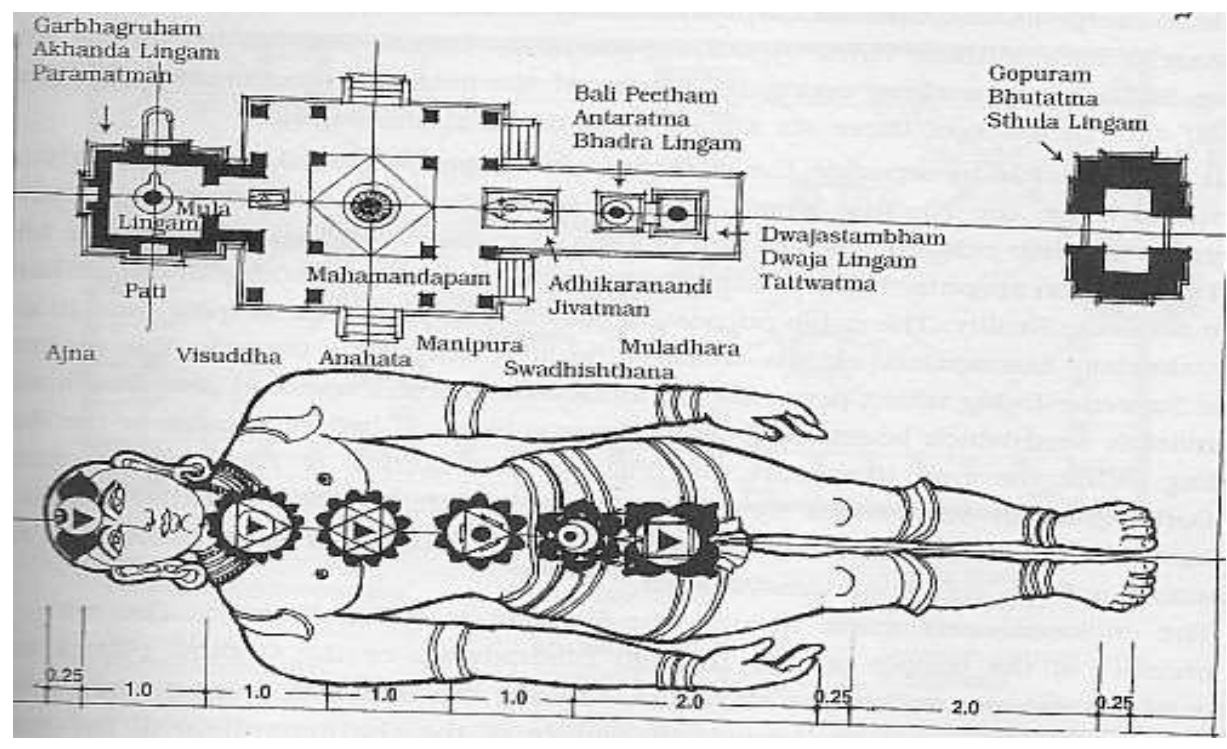

Gambar 5 Filosofi ruang dalam kuil Hindu (Sumber: https://sreenivasaraos.com)

\subsection{Unsur Vertikal dan Façade Kuil Shri Mariamman}

Kuil Hindu terdiri atas 3 (tiga) gaya bentuk yaitu, Nagara Style, Dravida Style dan Vesara Style. Bentuk Nagara Style berada pada India Utara dengan bentuk melengkung pada menaranya, sedangkan Dravida Style dan Vesara Style berada di India Selatan dengan perbedaan menaranya yaitu, Dravida Style menaranya berbentuk piramida dengan undakan yang makin mengecil keatas, sedangkan Vesara Style mengadopsi bentuk dari keduanya. Kuil Shri Mariaman mengambil pola bentuk Dravida Style dengan ciri mandapa sebagai ruang dasar, dan menara gopuram vimana yang berbentuk piramida.

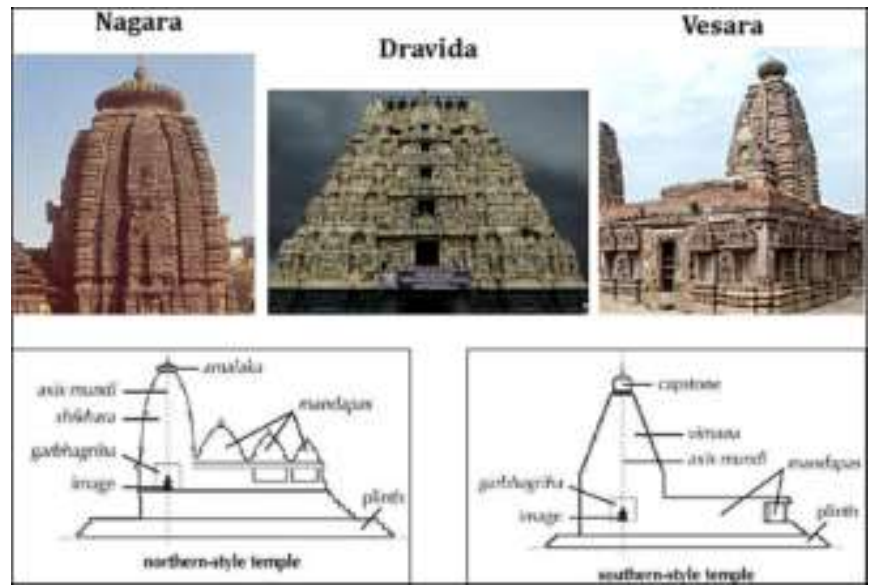

Gambar 6 Tiga gaya bentuk kuil Hindu

(sumber: https://www.quora.com/What-are-the-different-temple-architectural-styles-found-in-India) 
Fasad (kulit) bangunan Kuil Shri Mariamman dikelilingi tembok setinggi 2,5 meter. Dengan campuran warna pada dinding dan relief-relief pada kuil membuat bangunan ini kaya akan warna, budaya dan cerita. Didalam kuil terdapat patung-patung berbagai dewa dari umat Hindu. Dibagian depan pintu masuk ke kuil terdapat relief patung dewa Siwa pada bagian atas pintu dan disisi kiri dan kanan pintu terdapat patung Tuwarsakti yaitu penjaga dewi Shri Mariamman yang bertangan empat dengan trisula, gada dan pasa ditangannya.

Pada pintu gerbang terdapat sebuah Gopuram, yaitu menara bertingkat yang biasanya dapat ditemukan di pintu gerbang kuil-kuil Hindu diseluruh dunia. Dengan gaya arsitektur Dravidia khas India bangunan kuil ini mempunyai banyak relief-relief dan patung-patung yang menggambarkan kehidupan umat Hindu zaman dahulu.

\subsection{Ornamen Bangunan Kuil Shri Mariamman}

Ornamen yang ada di dalam Kuil Shri Marimman terdapat pada bagian dalam Kuil. Antara lain, dinding pembatas Mandapa, pintu masuk, gerbang masuk, Vimana dan kolom. Sedangkan ornamen yang terdapat di dalam kuil India Selatan terdiri dari patung patung Dewa, patung gajah dan kolom.

1. Ornamen yang ada pada Garhba Griha di Kuil Shri Mariamman terdapat banyak patung dewadewa Hindu dan jelmaan mereka yaitu Dewa Wisnu, Dewa Syiwa, dan Dewa Brahma. Ornamen Dewa-dewa di susun pada tingkat/undakan piramid.

2. Ornamen Mandapa. Pada dinding pembatas Mandapa terdapat ornamen dan gambar Dewa-Dewa yang menghiasi dinding tersebut. Ornamen Dewa pada dinding berwarna hitam. Sedangkan pada Lis tepi bagian luar atap mandapa terdapat ornamen burung bangau dengan latar belakang warna biru.

3. Ornamen Gopura. Gopura yang ada di Kuil Shri Mariamman berwarna biru dengan hiasan ornamen yang berwarna hijau

4. Ornamen dalam Mandapa. Pada sisi interior mandapa, teradapat kolom dengan ujung atas yang melengkung yang menghubungan antar kolom utama, pada lengkungan kolom terdapat banyak ornamen bunga dan manusia bersayap dan hiasan pita kalung. Latar belakang warna didominasi warna biru dan hijau.

5. Ornamen pada plafon terdapat bentuk ornamen bunga berwarna kuning dan merah.

\section{Metode}

Metode penelitian menggunakan jenis penelitian kualitatif yang menghasilkan data yang bersifat deskriptif mengenai layout, denah, tampak dan ornament yang diterapkan pada bangunan yang berupa data tertulis. Metode pengumpulan data yang digunakan adalah metode penelitian kualitatif. Pemilihan Objek Penelitian adalah Graha katolik Annai Velangkani dan bangunan kuil Shri Mariamman di Medan. Proses analisis data dilakukan setelah semua data terkumpulkan, lalu tahapan selanjutnya adalah melakukan pencocokan data dengan cara melihat penerapan karakteristik Arsitektur Kuil Hindu yang ada pada bangunan Graha Katolik Annai Velangkani, kemudian dapat ditarik kesimpulan.

\section{Analisis}

Desain utama Graha itu terinspirasi dari arsitektur Indo-Mogul sekaligus Graha kedua berarsitektur serupa setelah di India Selatan. Graha tersebut dihadirkan untuk mengakomodasi kebutuhan spiritual para umat Katolik keturunan India yang jumlahnya relatif banyak di Medan.

Di dunia cuma ada 2 (dua) Velangkanni: di India Selatan yang bentuknya lebih besar dan di Medan. Berikut ini akan dikaji tipologi kuil Hindu yang diterapkan pada Graha Katolik Graha Annai Velangkanni Medan.

Fungsi ruang lantai 1 adalah ruang serbaguna/aula, yang dibagi atas 4 area yaitu:

1. Teras

2. Aula

3. Panggung

4. Kantor 


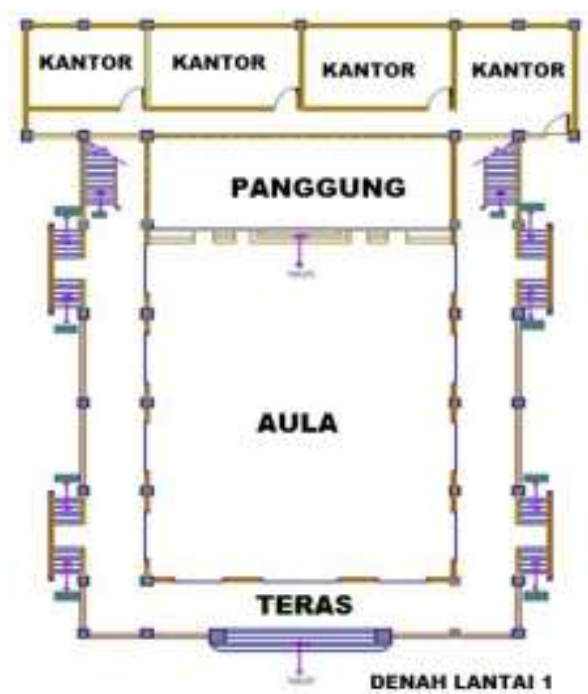

Gambar. 7 Denah Lantai 1 Aula Graha Annai Velangkanni (Sumber : Dokumentasi, Polin N, 2016)

Pada organisasi ruang kebaktian/ misa dilantai 2, terbagi atas 4 area yaitu:

1. Area publik yang merupakan ruang entrance masuk umat .

2. Area kudus/sakral yaitu ruang jemaat melakukan ibadah

3. Area Kudus yaitu ruang altar

4. Area Pelayanan yaitu kantor-kantor.

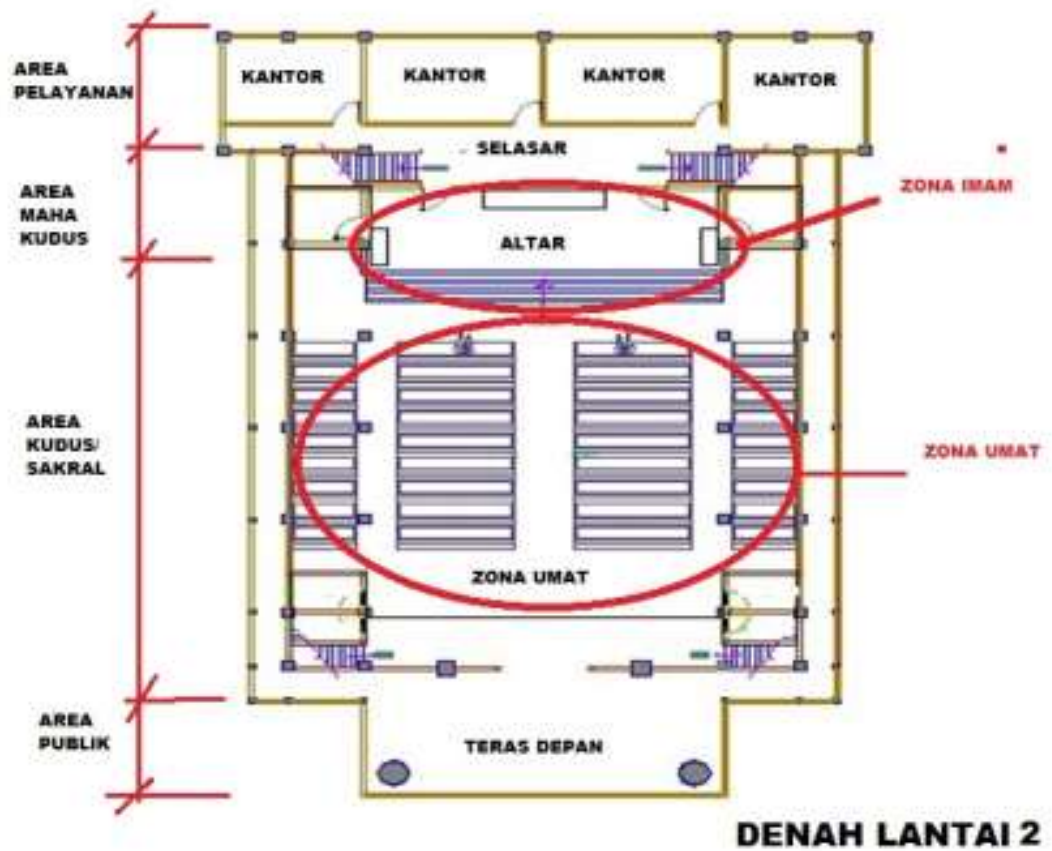

Gambar. 8 Denah Lantai 2 Aula Graha Annai Velangkanni (Sumber : Dokumentasi, Polin N, 2016) 
Jurnal Arsitektur AIJR - Vol 3 No 1 Mei 2020

e-ISSN 2685-1490; p-ISSN 2615-1472

Pada lantai 3 hanya terdapat balkon dan ruang selasar. Pada bagian selasar tiap kolom ada terdapat ornamen patung para rasul/santo Katolik.

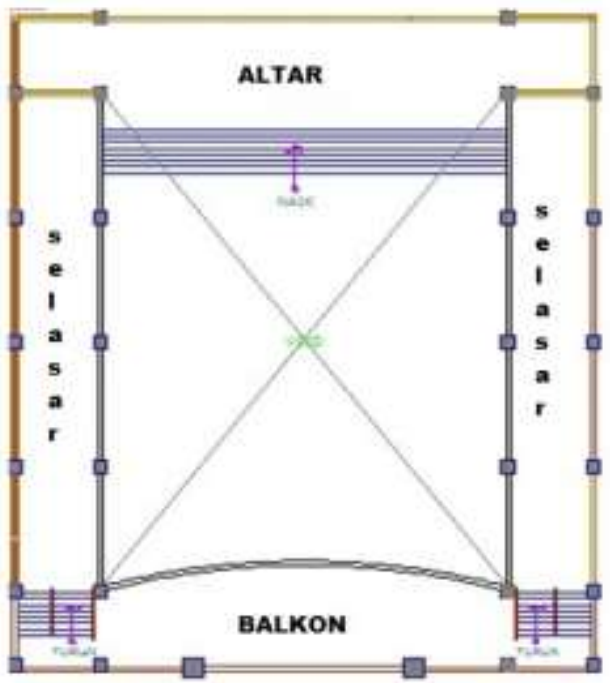

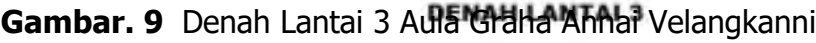

(Sumber : Dokumentasi, Polin N, 2016)

Pada organisasi ruang, Graha Annai Velangkani terutama pada kegiatan doa/misa pada lantai 2, mengikuti tipologi penataan ruang pada kuil Hindu, yaitu:

Tabel 1. Fungsi dan Ruang Utama pada kuil Hindu Shri Mariamman dan Graha Annai Velangkanni

\begin{tabular}{|c|c|c|c|}
\hline Kegiatan & Kuil Hindu Shri Mariamman & Graha Annai Velangkani & Keterangan \\
\hline Entrance & $\begin{array}{l}\text { Gopura/gopuram, } \\
\text { depan pintu masuk ke Kuil } \\
\text { sebelah kiri dan kanan terdapat } \\
\text { Arca Tuwarasakti (wanita } \\
\text { bertangan empat dengan } \\
\text { memegang trisula, gada dan } \\
\text { pasa) dan relif patung Dewa } \\
\text { Siwa di atas ambang pintu } \\
\text { masuk }\end{array}$ & $\begin{array}{l}\text { Teras Depan. } \\
\text { Dibagian depan pintu masuk } \\
\text { terdapat patung rasul/ orang } \\
\text { suci. Sebelah kiri patung St. } \\
\text { Fransiskus Xaverius, sebelah } \\
\text { kanan patung St. Paulus }\end{array}$ & $\begin{array}{lr}\text { Memiliki fungsi } \\
\text { yang sama } \\
\text { sebagai pintu } \\
\text { masuk dan } \\
\text { membuka } \\
\text { sepatu/sandal } \\
\text { sebelum masuk. }\end{array}$ \\
\hline Berdoa & $\begin{array}{l}\text { Mandapa, ruang persegi } \\
\text { panjang tanpa bangku duduk, } \\
\text { dibatasi oleh kolom-kolom } \\
\text { tunggal dan lantai dilapisi } \\
\text { sebagian dengan karpet yang } \\
\text { berfungsi untuk ruang doa, tari- } \\
\text { tarian, music dan untuk acara } \\
\text { pernikahan umat Hindu. }\end{array}$ & 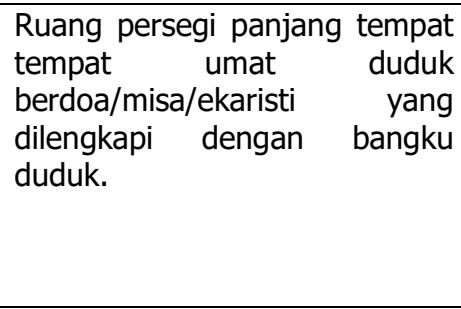 & \\
\hline $\begin{array}{l}\text { Kegiatan } \\
\text { Sakral }\end{array}$ & $\begin{array}{l}\text { Garbaha Griha, berupa bilik } \\
\text { khusus yang hanya boleh } \\
\text { dimasuki oleh iman, tanpa } \\
\text { perbedaan ketinggian lantai } \\
\text { dengan mandapa. }\end{array}$ & $\begin{array}{l}\text { Altar, ruang sakral tanpa sekat } \\
\text { yang dapat dibedakan secara } \\
\text { visual terhadap ruang umat } \\
\text { dengan adanya ketinggian } \\
\text { lantai }\end{array}$ & \\
\hline Pelayanan & Ruang penyimpanan & Ruang Kantor Pelayanan & $\begin{array}{l}\text { Terletak } \\
\text { belakang } \\
\text { bangunan }\end{array}$ \\
\hline
\end{tabular}

Sumber: Hasil Analisis, 2016 


\subsection{Kajian Unsur Vertikal dan Fasad Graha Annai Velangkani}

Graha Annai Velangkani memiliki 7 (tujuh) tingkatan bangunan yang melambangkan kesempurnaan dan tujuh langit, serta 3 (tiga) kubah yang melambangkan Ke-Tri Tunggalan Allah.

Menara pada Graha Annai Velangkanni mengikuti bentuk tipologi Vimana (atap) dari kuil Hindu Shri Mariamman, yaitu 7 undakan atau tingkat yang semakin meruncing keatas mengikuti bentuk piramid, dengan ornamen yang berbeda, yaitu ornamen tiga dimensi/patung pada kuil Hindu Shri Mariamman dan ornamen dua dimensi pada Graha Annai Velangkanni.

Menara yang semakin meruncing keatas menyimbolkan arah vertikal yaitu kesucian/kekudusan Tuhan atau Dewa.

Mahkota atau puncak dari menara pada Graha Annai Velangkanni berbentuk Cupola dengan pengertian kubah atau lengkung, sedangkan puncak dari menara vimana adalah bentuk datar dengan ujung lancip ditepi dan ditengahnya berdiri lempeng simbol cakra.

Tipologi bangunan Graha Annai Velangkani mengikuti bentuk dari kuil Hindu Shri Mariamman yaitu jenis kuil Dravida Style, yaitu satu puncak vemana dengan bentuk piramida sebagai puncak dari bilik garbaha giha. Perbedaan terletak pada posisi menara, dimana pada Graha Annai Velangkanni menara utama terletak di depan bangunan, dengan ukuran yang lebih tinggi sedangkan menara yang lebih kecil sebagai perwujudan dari menara garbaha griha terletak pada daerah altar.

Pada zona altar (lantai 2), terdapat bukaan atas yang tembus ke menara belakang sebagai tempat memasukkan cahaya dari atas sehingga ruang altar terasa lebih sakral dengan adanya pencahayaan alami dari atas menara. Tipologi ini diambil dari konsep tipologi bangunan kuil Hindu yaitu ruang garbaha griha yang menerus ke menara atap vemana.

\subsection{Kajian Ornamen dan Warna pada Graha Annai Velangkani}

Ornamen bangunan pada Graha Annai Velangkanni dijumpai di depan pintu masuk ruang aula lantai pertama yaitu adanya ornamen pohon pisang disebelah kiri dan kanan. Ornamen pohon pisang dalam kepercayaan Hindu tamil melambangkan kesuburan dan kemakmuran bagi suatu pernikahan. Pada tiang atas pintu terdapat ornamen pita yang menyerupai ornamen pada pintu masuk kuil Hindu Shri Mariamman

Ornamen bunga teratai terdapat pada landasan air mancur pada kolam didepan bangunan Graha dan pada tiang kolom dan bagian bawah kolom. Terdapat juga simbol burung disekeliling bagunan, bisa berarti simbol Roh Kudus, akan tetapi menurut perancangnya ini adalah simbol dari legenda India tentang burung Annam yang banyak terdapat pada kuil Hindu yang merupakan simbol tentang ajaran kebenaran (Azmi TS, 2016, http://harian.analisadaily.com/seni/news/simbol-spiritual-dan-dekorasi).

Pada lantai 2 (dua) Graha Annai Velangkanni, dibagian depan pintu masuk terdapat patung rasul/ orang suci. Sebelah kiri patung St. Fransiskus Xaverius, sebelah kanan patung St. Paulus.

Interior dalam Graha Annai Velangkanni penuh dengan ornament, relief dan lukisan serta aksara Tamil. Pada langit-langit Graha terdapat enam jenis sakramen yang diajarkan dalam iman Graha Katolik, yaitu : Permandian, Krisma, Pengampunan Dosa, Perkawinan, Imamat dan Pengurapan Orang Sakit. Pada pusat Graha yaitu ditengah altar ditempatkan Sakramen Ekaristi yang menjadi sakramen utama dalam iman katolik.

Pada jendela Graha terlukis Kisah Sengsara Tuhan Yesus. Terdapat 12 kolom didalam ruangan yang melambangkan 12 rasul/murid Tuhan Yesus dan 12 suku Israel.

Pada bagian tengah mimbar altar yang merupakan pusat view terdapat ornamen Perjamuan Terakhir Tuhan Yesus dengan murid-muridnya dengan posisi lesehan. Terdapat tiga lukisan di kubah altar berbentuk pohon Kalpataru yang menggambarkan kedatangan Yesus untuk kedua kalinya dan pengadilan terakhir.

Pada sisi bawah altar sebelah kiri dan kanan terdapat bilik berongga yang didalamnya terdapat patung Bunda Maria dan patung Tuhan Yesus (dengan perawakan India).

Warna-warna yang mendasari bangunan Graha beserta makna filosofi yang terkandung didalamnya adalah:

1) WARNA HITAM: menggambarkan sosok manusia yang hidup dalam kegelapan dan kedosaan (hitam)

2) WARNA ABU-ABU: dianggap sebagai simbol pertobatan dalam Alkitab. Warna dominan adalah abu-abu, yang menggambarkan untuk memberitakan pertobatan kepada semua yang datang padanya.

3) WARNA PUTIH: orang berdosa bersujud memohon belas kasihan Tuhan untuk menjadi murni dan suci (putih) yang berarti juga pertobatan. 
Jurnal Arsitektur AIUR - Vol 3 No 1 Mei 2020

e-ISSN 2685-1490; p-ISSN 2615-1472

4) WARNA MERAH: setelah manusia menjadi kudus (putih) melalui pertobatan dan juga ingin tetap dalam kekudusan seterusnya dia harus senantiasa mengorbankan dirinya (merah).

5) WARNA HIJAU: ketika seorang manusia kehilangan hidupnya melalui pengorbanan dirinya demi Allah dan demi orang lain, ia akan memiliki hidup Ilahi dalam dirinya.

6) WARNA BIRU: kalau manusia sudah memiliki hidup ilahi di dalam dirinya, sudah barang tentu ia juga memiliki hak untuk masuk kedalam surga (biru)

7) WARNA KUNING: dan ketika manusia masuk surga, Allah akan memuliakan dia dalam kemuliannya yang kekal (kuning emas) seperti yang kelihatan diatas tiga kubah menara Graha.

\section{Kesimpulan dan Saran}

Berdasarkan hasil analisa maka dapat disimpulkan kaidah tipologi bangunan kuil Hindu (subjek bangunan Kuil Shri Mariamman) yang menjadi dasar penerapan pada bangunan Graha Katolik Annai Velangkanni sebagai berikut:

Pada dasarnya pola dari ruang ibadah baik dari kuil maupun Graha adalah sama yaitu berbentuk persegi panjang, sequence (alur) ruang juga sama yaitu dari ruang tidak suci (teras) - ruang suci (umat) - ruang maha suci/sakral (imam). Perbedaan yang ada terletak pada kuil Hindu yaitu ruang suci/mandapa tidak ada bangku untuk umat atau perabot selain patung dan hiasan, mandapa juga difungsikan sebagai tempat tari-tarian, pernikahan, sehingga ruangan Mandapa difungsikan dengan lantai tanpa perabot/ kursi. Sedangkan ruang umat pada Graha Annai Velangkanni difungsikan dengan kursi untuk umat

Tabel 2 Unsur vertikal ornamen dan warna

\begin{tabular}{|c|c|c|}
\hline Unsur & Kuil Shri Mariaman & Graha Annai Velangkani \\
\hline $\begin{array}{l}\text { a. Tipologi } \\
\text { sumbu vertikal } \\
\text { horisontal }\end{array}$ & southern-style temple & 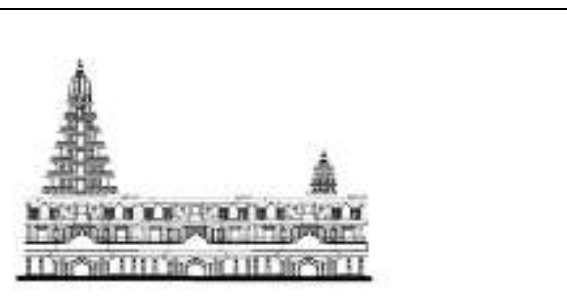 \\
\hline $\begin{array}{l}\text { b. Tingkat } \\
\text { Menara }\end{array}$ & $\begin{array}{l}7 \text { tingkat pada Vimana dan berbentuk } \\
\text { piramid }\end{array}$ & $\begin{array}{l}7 \text { tingkatan dengan bentuk piramid } \\
\text { yang diakhiri dengan kubah. }\end{array}$ \\
\hline c.Ujung Menara & $\begin{array}{l}\text { BENTUK UJUNG VIMANA } \\
\text { KUIL HINDU BHRI } \\
\text { MARIAMMAN }\end{array}$ & $\begin{array}{l}\text { BENTUK UJUNG MENARA GEREJA ANNAI } \\
\text { VELANGKANNI }\end{array}$ \\
\hline
\end{tabular}




\begin{tabular}{|c|c|c|}
\hline d. Ornamen & $\begin{array}{l}\text { - Ornamen berbagai binatang dan } \\
\text { bunga teratai. } \\
\text { - Patung dewa }\end{array}$ & 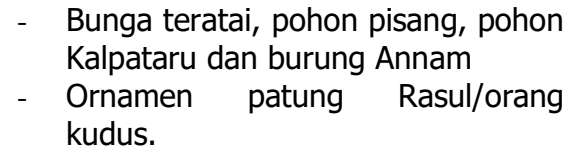 \\
\hline e. Warna & Dominasi warna Biru dan Hijau & Dominasi warna Abu-abu \\
\hline
\end{tabular}

(Sumber: Hasil Analisis, 2016)

\section{Daftar Pustaka}

Sulistijowati, M. (1991). Tipologi Arsitektur Pada Rumah Kolonial Surabaya (Dengan Kasus Perumahan Plampitan dan Sekitarnya). Tidak dipublikasikan. Surabaya: Pusat Penelitian Institut Teknologi Sepuluh November.

Soekiman, D. 2000. Kebudayaan Indis dan Gaya Hidup Masyarakat Pendukungnya di Jawa (Abad XVIII-Medio Abad $X X)$. Yogyakarta: Yayasan Bentang Budaya.

Amiuza, C. 2006. Tipologi Rumah Tinggal Administratur P.G. Kebon Agung di Kabupaten Malang. Jurnal RUAS. IV (1): $1-22$.

Kusmiati, A. 2004. Dimensi Estetika pada Karya Arsitektur \& Desain. Jakarta: Djembatan.

Deer Hoop, Van. 1949. Ragam-Ragam Perhiasan Indonesia. Batavia: Konklijk Genootsha Van Kunsten En Wetenshappen.

Sipahelelut, A. \& Petrussumadi. 1991. Dasar-Dasar Desain. Jakarta: Departemen Pendidikan dan Kebudayaan.

Putri Indah Sari, Kajian Karakteristik Arsitektur Hindu Pada Kuil Shri Mariamman Medan, https://www.academia.edu. 